\title{
The Stakes of History
}


The Franz Rosenzweig Lectures in Jewish Theology and History are sponsored by the Program in Judaic Studies at Yale University. The Lectures were established in 1987 by the Estate of Arthur A. Cohen and are named for theologian Franz Rosenzweig.

Other volumes in the Franz Rosenzweig Lecture series available from Yale University Press

Radical Judaism: Rethinking God and Tradition, by Arthur Green

Canon and Creativity: Modern Writing and the Authority of Scripture, by Robert Alter

German Jerws: A Dual Identity, by Paul Mendes-Flohr Freud's Moses: Judaism Terminable and Interminable, by Yosef Hayim Yerushalmi 


\section{The Stakes of History}

On the Use and Abuse

of Jewish History for Life

David N. Myers 
Published with assistance from the Franz Rosenzweig Lectures in Jewish Theology and History Fund in the Program in Judaic Studies at Yale University.

Published with assistance from the foundation established in memory of Calvin Chapin of the Class of r788, Yale College.

Copyright () 2018 by Yale University. All rights reserved.

This book may not be reproduced, in whole or in part, including illustrations, in any form (beyond that copying permitted by Sections ro7 and Io8 of the U.S. Copyright Law and except by reviewers for the public press), without written permission from the publishers.

Yale University Press books may be purchased in quantity for educational, business, or promotional use. For information, please e-mail sales.press@yale.edu (U.S. office) or sales@yaleup.co.uk (U.K. office).

Set in Caslon type by Integrated Publishing Solutions. Printed in the United States of America.

Library of Congress Control Number: 2017937446 ISBN 978-0-300-22893-9 (hardcover : alk. paper)

A catalogue record for this book is available from the British Library.

This paper meets the requirements of ANSI/NISO Z 39.48-1992 (Permanence of Paper).

IO 987655432 I 
To Sondra and Morey Myers 
This page intentionally left blank 